\title{
Inhibitory effect of the essential oil from Eugenia caryophyllata Thumb leaves on coalho cheese contaminating microorganisms
}

\author{
Efeito inibitório do óleo essencial das folhas de Eugenia caryophyllata Thumb \\ sobre microrganismos contaminantes de queijo de coalho
}

\author{
Vinicius Nogueira TRAJANO ${ }^{1}$, Edeltrudes de Oliverira LIMA ${ }^{1}$, \\ Evandro Leite de SOUZA ${ }^{2 *}$, Antônio Eustáquio Resende TRAVASSOS ${ }^{3}$
}

\begin{abstract}
Coalho cheese (a firm but very lightweight cheese produced in Brazil) is widely produced and consumed in the Brazilian Northeast and its production has been mainly related to small farmers. This food has been frequently characterized as having high microbial load posing a risk for the health of consumers. This study aimed to indentify the chemical compounds of the essential oil from Eugenia caryophyllata leaves; to evaluate the inhibitory effect of the oil against coalho cheese contaminating microorganisms; and to assess its efficacy in inhibiting the autochthonous microflora of the cheese during refrigerated storage. Eugenol (74\%) was found to be the most prevalent compound in the essential oil. Minimum Inhibitory Concentration (MIC) and Minimum Cidal Concentration (MCC) in laboratorial broth were in the range of 2.5-5 and 5-20 $\mu \mathrm{g} \cdot \mathrm{mL}^{-1}$, respectively. Vaccum packed coalho cheese added with 5, 10, and $20 \mu \mathrm{g} . \mathrm{g}^{-1}$ of oil showed a lower growth rate (like-static effect) against mesophilic bacteria during the time intervals evaluated. On the other hand, $2.5-10 \mu \mathrm{g} . \mathrm{g}^{-1}$ of oil provided a prominent decrease toward fungi count in cheese samples during storage. These results reveal the interesting antimicrobial property of the essential oil from E. caryophyllata leaves against a range of coalho cheese-related microorganisms in laboratorial media and in food matrix.
\end{abstract}

Keywords: coalho cheese; E. caryophyllata; antimicrobial property.

\section{Resumo}

O queijo de coalho é amplamente produzido e consumido na região Nordeste do Brasil, sendo principalmente fabricado por pequenos produtores rurais. Este produto tem sido caracterizado por uma alta carga microbiana, significando um risco para a saúde dos consumidores. Este estudo teve como objetivo identificar os compostos químicos do óleo essencial extraído das folhas de Eugenia caryophyllata; avaliar o efeito inibitório do óleo essencial sobre microrganismos contaminantes de queijo de coalho; e verificar sua eficácia em inibir a microflora autóctone do produto durante o armazenamento refrigerado. Eugenol (74\%) apresentou-se como o composto mais prevalente no óleo essencial. Os valores de Concentração Inibitória Mínima (CIM) e Concentração Microbicida Mínima (CMM) em meio sintético variaram entre 2,5-5 e 5-20 $\mu \mathrm{g} \cdot \mathrm{mL}^{-1}$, respectivamente. As amostras de queijo de coalho embaladas a vácuo e adicionadas de 5, 10 e $20 \mu \mathrm{g} . \mathrm{g}^{-1}$ de óleo essencial apresentaram uma menor taxa de crescimento (efeito microstático) de bactérias mesófilas ao longo dos intervalos avaliados. De outra forma, o óleo essencial em concentrações variando entre 2,5 e $10 \mu \mathrm{g} \cdot \mathrm{g}^{-1}$ causou considerável redução da contagem de fungos nas amostras de queijo ao longo do armazenamento. Estes resultados revelam a destacável propriedade antimicrobiana do óleo essencial extraído das folhas de E. caryophyllata frente a uma variedade de microrganismos contaminantes de queijo de coalho em meio laboratorial e na matriz alimentar. Palavras-chave: queijo de coalho; E. caryophyllata; propriedade antimicrobiana.

\section{Introduction}

Coalho cheese is a soft cheese obtained after milk coagulation using curdle or proper coagulating-enzymes, sometimes complemented with the use of selected lactic bacteria, and commonly marketed until 10 days of refrigerated storage. It is known as an intermediate moisture cheese with a mild acidic flavor and fat content in the range of $35-60 \%$ in dry matter (BRASIL, 1996). This variety of cheese is widely produced and consumed in the Brazilian Northeast region, and the major production has been attributed to small farmers (SENA; CERQUEIRA; MORAIS, 2000).
Many studies have found a variety of classical and emerging pathogen microorganisms in samples of coalho cheese and its microbial load have worried the regulatory agencies regarding its impact on the public health (PERESI et al., 2001). In addition of establishing and introducing practices in order to minimize the sources of microbial contamination of coalho cheese during its processing, some authors reported the necessity of evaluating the efficacy of classical and alternative chemical or physical procedures for controlling the microbial growth during its storage (CAVALCANTE et al., 2007).

Recebido para publicação em 22/10/2008

Aceito para publicação em 23/6/2009 (003906)

${ }^{1}$ Departamento de Ciências Farmacêuticas, Centro de Ciências da Saúde, Universidade Federal da Paraíba - UFPB, João Pessoa - PB, Brasil

${ }^{2}$ Laboratório de Microbiologia de Alimentos, Departamento de Nutrição, Centro de Ciências da Saúde, Universidade Federal da Paraíba - UFPB, Campus I, CEP 58051-900, Cidade Universitária, João Pessoa - PB, Brasil, E-mail: evandroleitesouza@ccs.ufpb.br

${ }^{3}$ Departamento de Tecnologia Rural, Universidade Federal da Paraíba - UFPB, Bananeiras - PB, Brasil

${ }^{*}$ A quem a correspondência deve ser enviada 
The increased demand for safe and natural food, without chemical preservatives, has stimulated researchers to investigate the antimicrobial efficacy of many natural compounds against some food-related pathogen microorganisms. The antimicrobial potential of essential oils has been of great interest in both academia and food industry since their possible use as natural additives emerges from a growing tendency to replace synthetic additives (SAMAPUNDO et al., 2007).

Eugenia caryophyllata Thumb (Myrtaceae), popularly known as clove, is native from Moluca Islands. Eugenol, eugenol acetate, and $\beta$-cariophyllene have been found in the essential oils obtained from their leaves, and these compounds are described as having prominent antimicrobial property (DEANS, 1995; NUNEZ; AQUINO, 2001; MOREIRA et al., 2005). Although some studies have reported the inhibitory effect of the essential oil from E. caryophyllata on some food-related pathogen and spoilage microorganism in synthetic media, there has been a lack of data about its efficacy when applied in food matrices, particularly in soft cheeses. Previous studies have revealed interesting antimicrobial efficacy in essential oils obtained from E. caryophyllata flowers (CHAIEB et al., 2007); however few reports have focused on the antimicrobial properties of essential oils obtained from those leaves.

The aim of this study was to identify the constituents of the essential oil from E. caryophyllata leaves; to verify its inhibitory effect on the growth of coalho cheese contaminating microorganisms; and to assess its efficacy to inhibit the autochthonous microflora of the coalho cheese during refrigerated storage.

\section{Material and methods}

\subsection{Essential oil}

The essential oil from E. caryophyllata leaves was obtained from Ferquima Ind. e Com. Ltda. (Vargem Grande Paulista, São Paulo, Brazil), and its quality parameters (appearance, color, purity, odor, density $-20{ }^{\circ} \mathrm{C}$, and refraction index $-20{ }^{\circ} \mathrm{C}$ ) were described in a accompanying technical report. This provider extracts essential oils in industrial scale using the hydrodistillation procedure. With regard to the antimicrobial assays, the essential oil was assayed at 160,$80 ; 40 ; 20 ; 10 ; 5$, $2.5 ; 1.25$, and $0.62 \mu \mathrm{g} \cdot \mathrm{mL}^{-1}$, and the solutions were prepared according to Souza et al. (2007).

\subsection{Essential oil chemical analysis}

The essential oil chemical composition was analyzed using a Gas Chromatograph (GC) fitted to a Mass Spectrophotometer (MS) (GC-MS, Shimadzu QP-5000, Kyoto, Japan) operating in electron-impact (70 eV, m/z 40 - 450) mode. The fused-silica capillary column used was an OV-5 with diameter of $30 \mathrm{~m}$ long., $0.25 \mathrm{~mm}$ i.d., $0.25 \mu \mathrm{m}$ film thickness (Ohio Valley Special Chemical Inc., USA). The chromatographic conditions were as follows: sample preparation $1 \mu \mathrm{L}$ in $1 \mathrm{~mL}$ of hexane; injection volume $1 \mu \mathrm{L}$; split ratio 1:55; helium flow rate $1.0 \mathrm{~mL} /$ minute; temperature programme ramp from 60 to $240^{\circ} \mathrm{C}$ with a gradient of $3{ }^{\circ} \mathrm{C} /$ minute (holding the initial and final temperature for 10 minutes); injector temperature $240{ }^{\circ} \mathrm{C}$; and detector temperature $230{ }^{\circ} \mathrm{C}$.
The identification of the essential oil components was performed by retention indexes and by comparing their mass spectra with a data bank (System GC-MS, Nist. 62 lib) and the literature (ADAMS, 1995; McLAFFERTY; STAUFFER, 1989). The retention indexes were obtained by co-injection with a hydrocarbons $\left(\mathrm{C}_{9}-\mathrm{C}_{24}\right)$ standard mixture using the van Den Doll equation (van DEN DOOL; KRATZ, 1963).

\subsection{Test microorganisms}

The test microorganisms used in the antimicrobial assays were chosen based on their importance as coalho cheese contaminant according to previous studies (FEITOSA et al., 2003; LEITE JUNIOR et al., 2000). Regarding this criteria, the bacteria Listeria monocytogenes ATCC 7664, Pseudomonas aeruginosa ATCC 9027, Staphylococcus aureus ATCC 6538, Salmonella enterica ATCC 6017 and Yersinia enterocolitica ATCC 9610; and the yeasts Candida albicans ATCC 90028, C. parapsilosis LM-10, C. krusei ATCC 6252, and C. tropicalis MD 37 were used as test microorganisms.

Bacteria and yeast cultures were kept on Nutrient Agar (NA) and Sabouraud Agar (SA) slants at $4{ }^{\circ} \mathrm{C}$, respectively. The inocula were obtained from overnight cultures grown on NA slants at $37{ }^{\circ} \mathrm{C} / 24$ hours (for bacteria) or SA slants at $25^{\circ} \mathrm{C} / 48$ hours (for yeasts) and diluted in sterile saline solution $\left(\mathrm{NaCl} 0.85 \mathrm{~g} .100 \mathrm{~mL}^{-1}\right)$ to provide a final concentration of approximately $10^{6}$ count forming unit per $\mathrm{mL}\left(\mathrm{cfu} \cdot \mathrm{mL}^{-1}\right.$ ) adjusted according to the turbidity of $0.5 \mathrm{McF}$ arland scale tube.

\subsection{Determination of the minimum inhibitory concentration and minimum cidal concentration}

Microplate bioassay was used for determining the Minimum Inhibitory Concentration (MIC) of the essential oil on the test microorganisms. The microplates were prepared by dispensing into each well $100 \mu \mathrm{L}$ of double strength Nutrient broth or Sabouraud broth inoculated with the bacteria or yeast inoculum, respectively, prior to the assay. An aliquot $(100 \mu \mathrm{L})$ of the essential oil solutions at their respective concentrations adjusted for $200 \mu \mathrm{L}$ was transferred into the wells. No essential oil was transferred into the last well. The microplate was aseptically sealed, followed by mixing on a plate shaker $(300 \mathrm{rpm})$ for 30 seconds, and incubated at $37^{\circ} \mathrm{C} / 24$ hours and $25^{\circ} \mathrm{C} / 48$ hours for bacteria and yeast, respectively (VILJOEN et al., 2003; SAHIN et al., 2004).

Bacterial inhibition was detected using a colorimetric method by adding $200 \mu \mathrm{L}$ of resauzurin staining $\left(0.1 \mathrm{~g} .100 \mathrm{~mL}^{-1}\right)$ aqueous solution in each well at the end of the incubation period. MIC was defined as the lowest essential oil concentration able to inhibit bacteria growth, as indicated by resauzurin staining (dead bacteria cells are not able to change the staining color by visual observation - blue to red) (BURT; REINDERS, 2003). For yeasts, MIC was defined as the lowest concentration of the essential oil able to provide visible yeast growth inhibition after the end of the incubation period (ESPINEL-INGROF et al., 1992). An aliquot $(100 \mu \mathrm{L})$ of the wells with no microbial growth was subcultured on sterile NA at $37^{\circ} \mathrm{C} / 24$ hours and $\mathrm{SA}$ at $25^{\circ} \mathrm{C} / 48$ hours for bacteria and yeast, respectively, to determine whether the inhibition was reversible or permanent. Minimum Cidal Concentration (MCC) was defined as the lowest concentration at which no growth was noted on the agar. 


\subsection{Effect of oil in food matrix}

In order to assess the effect of the essential oil toward the autochthonous microflora of the food matrix, samples of coalho cheeses were prepared using uncooked milk according to the procedure described by Cavalcante et al. (2007) with minor changes (Figure 1). The cheeses were divided into five groups: i) cheese added with $20 \mu \mathrm{g} \cdot \mathrm{g}^{-1}$ of the oil; ii) cheese added with $10 \mu \mathrm{g} . \mathrm{g}^{-1}$ of the oil; iii) cheese added with $5 \mu \mathrm{g} \cdot \mathrm{g}^{-1}$ of the oil; iv) cheese added with $2.5 \mu \mathrm{g} \cdot \mathrm{g}^{-1}$ of the oil; and v) cheese without oil (control). The cheeses were vacuum packed and storage at $4^{\circ} \mathrm{C}$ up to microbiological analysis.

At 1, 7, and 14 days of storage, the cheese samples were submitted to analysis of mesophilic bacteria and fungi count according to the procedure described by Vanderzant and Splittstoesser (1992). The samples of the cheeses were

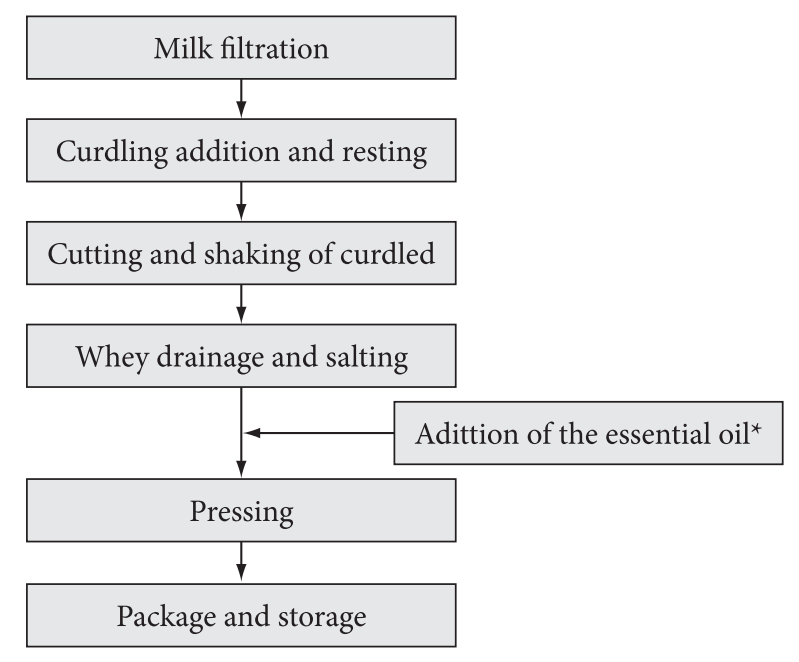

Figure 1. Steps involved in the production of coalho cheese added with essential oil from E. caryophyllata leaves ( ${ }^{*}$ not for control cheese). weighted and serially diluted $\left(10^{-1}-10^{-6}\right)$ in peptone water ( $\left.0.85 \mathrm{~g} .100 \mathrm{~mL}^{-1}\right)$. Aliquots of $1 \mathrm{~mL}$ were plated onto Plate Count agar $\left(35^{\circ} \mathrm{C} / 24\right.$ hours $)$ and SA $\left(25^{\circ} \mathrm{C} / 72\right.$ hours $)$ for the analysis of mesophilic bacteria and fungi, respectively. The counts were given in log of cfu per gram of cheese (log cfu.g ${ }^{-1}$ cheese).

\subsection{Statistical analysis}

All antimicrobial assays were performed in triplicate and the results are expressed as average of the parallel assays. Statistical analyses of data obtained in antimicrobial assays were carried out to determine significant differences $(\mathrm{p}<0.05)$ by Tukey test using the Sigma stat 3.1 computer software.

\section{Results e discussion}

The composition of the essential oil from E. caryophyllata leaves was analyzed by using GC-MS leading the comparison of the relative retention times and the mass spectra of oil components with those of authentic samples and mass spectra from a data library. As shown in Table 1, GC-MS of the oil resulted in the identification of 18 compounds making $100 \%$ of the oil. Eugenol (74\%) was the most prevalent compound, followed by a-humullene (9.62\%), d-cadinene (4.64\%), trans$\beta$-cariophyllene $(4.69 \%)$, and cariophyllene oxide $(1.63 \%)$. Other compounds such as eucalyptol $(0.96 \%), \gamma$-cadinene $(0.86 \%)$, humullene $(0.83 \%)$, and torreyol $(0.62 \%)$ were found in minor percent. The oil showed to be constituted of different sesquiterpenes (trans- $\beta$-cariophyllene, $\alpha$-humullene, cariophyllene oxide, and d-cadinene), monoterpenes ( $\alpha$-pinene eucaliptol, linalool) and phenylpropanoid (eugenol). In accordance with our results Fichi et al. (2007) studying the composition of the oil from E. caryophyllata leaves found eugenol (76.80\%), trans- $\beta$-caryophyllene (17.4\%), $\alpha$-humullene (9.62\%), cariophyllene oxide (1.63\%), and eucaliptol (0.1\%).

Table 1. GC-MS analysis of the essential oil from E. caryophyllata leaves (results expressed in percent of oil total mass).

\begin{tabular}{|c|c|c|c|}
\hline Peak & Retention time (minute) & Compound & Percent \\
\hline 1 & 5.625 & a-pinene & 0.04 \\
\hline 2 & 8.522 & eucaliptol & 0.96 \\
\hline 3 & 11.008 & linalool & 0.03 \\
\hline 4 & 22.767 & eugenol & 74.0 \\
\hline 5 & 25.524 & trans- $\beta$-cariophyllene & 4.29 \\
\hline 6 & 27.067 & a-humullene & 9.62 \\
\hline 7 & 27.552 & $\gamma$-cadinene & 0.86 \\
\hline 8 & 28.552 & torreyol & 0.62 \\
\hline 9 & 28.881 & farnesene & 0.44 \\
\hline 10 & 29.609 & d-cadinene & 4.64 \\
\hline 11 & 30.633 & cyclohexane, 2,3-dimethyl-1,5-divinil & 0.63 \\
\hline 12 & 30.858 & biscyclo[3.3.1]nonan-2-one, 7-etenil-7-metil-eno & 0.36 \\
\hline 13 & 31.325 & palustrol & 0.32 \\
\hline 14 & 31.815 & cariophyllene oxide & 1.63 \\
\hline 15 & 32.854 & humullene & 0.83 \\
\hline 16 & 33.525 & carotol & 0.33 \\
\hline 17 & 33.825 & isolimonene & 0.18 \\
\hline 18 & 34.617 & viridiflorol & 0.22 \\
\hline
\end{tabular}


The composition of essential oils may change based on the differences of origin, vegetative state, growing season, and part of the plant that is used for oil extraction. However, changes in the compounds of E. caryophyllata leaves essential oil are found to be mainly of quantitative profile since the variance in major compounds is taken as criteria for indentifying different chemotypes (SAMARASEKERA; KALHARI; WEERASINGHE, 2005).

Microdilution assay was used to find MIC and MCC of the oil from E. cariophyllata leaves against some coalho cheeserelated bacteria and yeasts (Table 2). The oil exhibited interesting inhibitory activity toward all assayed microbial strains. MIC and MCC were in a range of $2.5-5$ and $5-20 \mu \mathrm{g} \cdot \mathrm{mL}^{-1}$, respectively. Smallest MIC $\left(2.5 \mu \mathrm{g} \cdot \mathrm{mL}^{-1}\right)$ was found against Y. enterocolitica, C. albicans, C. parapsilosis, and C. krusei. $20 \mu \mathrm{g} . \mathrm{mL}^{-1}$ of oil showed cidal effect against the bacteria, while for yeasts it was in the range of 5-10 $\mu \mathrm{g} \cdot \mathrm{mL}^{-1}$. Assayed concentrations of the oil provided no cidal effect toward $P$. aeruginosa. Some authors found $P$. aeruginosa as the Gram negative bacteria less sensitive to essential oils (RUBERTO et al., 2000; WILKINSON et al., 2003).

The cidal concentration of E. cariophyllata leaves essential oil against yeasts was two or four-fold higher than MIC, while for bacteria it was four or eight-fold higher. In accordance to our findings, previous studies that reported higher sensitivity of yeasts to essential oils in comparison to bacteria (ARORA; KAUR, 1999; VILJOEN et al., 2003). Smith-Palmer, Stewart and Fyfe (1998) found that the oil form $E$. caryophyllata leaves provided a static effect on the growth of Campylobacter jejuni, S. enteritidis, Escherichia coli, S. aureus, and L. monocytogenes.

The antimicrobial efficacy of essential oils depends on their composition and target microorganism. Eugenol, a phenolic found as the major compound in E. caryophyllata leaves essential oil, is believed to have antibacterial property by the inhibition of extracellular enzymes synthesis and disruption of the cell wall structure resulting in lack of cytoplasm, cytoplasm granulation, cytoplasm hyperacidity, and depletion of intracellular ATP pool (LOPEZ-DÍAS et al., 2002). Still, oxygenated and hydrocarbon terpenes (e.g. humullene, eucalyptol, torreyol, and $\gamma$-cadinene) found in the oil accumulate in the microbial membrane causing a loss of the membrane integrity, leakage of cytoplasmatic content, dissipation of the proton motive force, and cell lysis (SIKKEMA; BONT; POOLMAN, 1995; GUSTAFSON et al., 1998).

The number of studies regarding the antimicrobial activity of spices and derivatives in food matrix can still be considered small when compared to the number of studies using laboratorial media. It is expected that the efficacy of an antimicrobial is influenced by several factors such as the food $\mathrm{pH}$, presence of several food components, and storage temperature (DEVLIEGHERE; DEBEVERE, 2004).

The effect of E. caryophyllata leaves essential oil at 2.5, 5, 10 , and $20 \mu \mathrm{g} . \mathrm{g}^{-1}$ on the count of mesophilic bacteria and fungi in vacuum packed coalho cheese during the refrigerated storage is shown in Figures 2 and 3, respectively. These concentrations were chosen regarding the range of values found as MIC and MCC. With respect to the problem of the high microbial counts in coalho cheese, the assayed oil seemed to disturb the growth kinetics of mesophilic bacteria and fungi in a dose-dependent manner.

The oil at 2.5-20 $\mu \mathrm{g} \cdot \mathrm{g}^{-1}$ caused a decrease in the growth rate of mesophilic bacteria in comparison to that noted for the control assay over the 15 days of storage. Cheeses added with the oil at 5,10, and $20 \mu \mathrm{g} \cdot \mathrm{g}^{-1}$ showed a significantly lower $(\mathrm{p}<0.01)$ bacterial count with respect to the control assay during the evaluated time intervals. The oil at $2.5-10 \mu \mathrm{g} . \mathrm{g}^{-1}$ provided a static effect on the fungi growth during the assessed time intervals, while at $20 \mu \mathrm{g} \cdot \mathrm{g}^{-1}$ caused a linear decrease in the count during storage. The addition of the oil at 2.5-20 $\mu \mathrm{g} \cdot \mathrm{g}^{-1}$ resulted in a significantly lower fungi count in comparison to that of the control assay. Although the assayed cheeses presented high microbial load already at zero time, the oil exerted interesting inhibition on their microbial load. These high counts could be related to the use of uncooked milk as raw material for preparing the cheeses used as food-model.

Smith-Palmer, Stewart and Fyfe (2001) reported that the essential oils from E. caryophyllata and C. zeylanicum caused a dose and time-exposure dependent decrease in L. monocytogenes and S. enteritidis in soft cheese. Menon and Garg (2001) noted that the count of L. monocytogenes was decreased at 1 to $5 \log$ cycles in meat added with E. caryophyllata essential oil at 5 and $10 \mu \mathrm{L} . \mathrm{g}^{-1}$. The same authors reported that the efficacy of essential oils in vacuum packed foods is possibly increased in despite of the smaller volatility of the oil.

Although E. caryophyllata essential oil at 5 and $10 \mu \mathrm{g} \cdot \mathrm{g}^{-1}$ has showed cidal effect on the fungi at microplate bioassay, only a static effect was noted in cheese model. Oil loss (leakage) in some extent during the cheese pressing (MENON; GARG, 2001) and the amount of fat and protein in the cheese could cause a decreased availability of the compound to exert its antimicrobial effect (GUTTIERREZ et al., 2008). Moreover, it is suggested that the greater availability of nutrients in foods compared to laboratory media may enable bacteria to repair damaged cells faster (GILL et al., 2002).

Table 2. In vitro MIC, MFC and MBC of the essential oil from E. caryophyllata leaves against some coalho cheese related microorganisms.

\begin{tabular}{lcc}
\hline \multicolumn{1}{c}{ Microorganisms } & \multicolumn{2}{c}{ Essential oil $\left(\mu \mathrm{g} . \mathrm{mL}^{-1}\right)$} \\
\cline { 2 - 3 } & MIC & MCC \\
\hline L. monocytogenes ATCC 7664 & 5 & 20 \\
P. aeruginosa ATCC 27853 & 5 & - \\
S. aureus ATCC 25923 & 5 & 20 \\
S. enterica ATCC 6017 & 5 & 20 \\
Y. enterocolitica ATCC 9610 & 2.5 & 20 \\
C. albicans ATCC 90028 & 2.5 & 5 \\
C. parapsilosis LM-10 & 2.5 & 10 \\
C. krusei ATCC 6252 & 2.5 & 5 \\
C. tropicalis MD 37 & 5 & 5 \\
L. monocytogenes ATCC 7664 & 5 & 5 \\
\hline
\end{tabular}




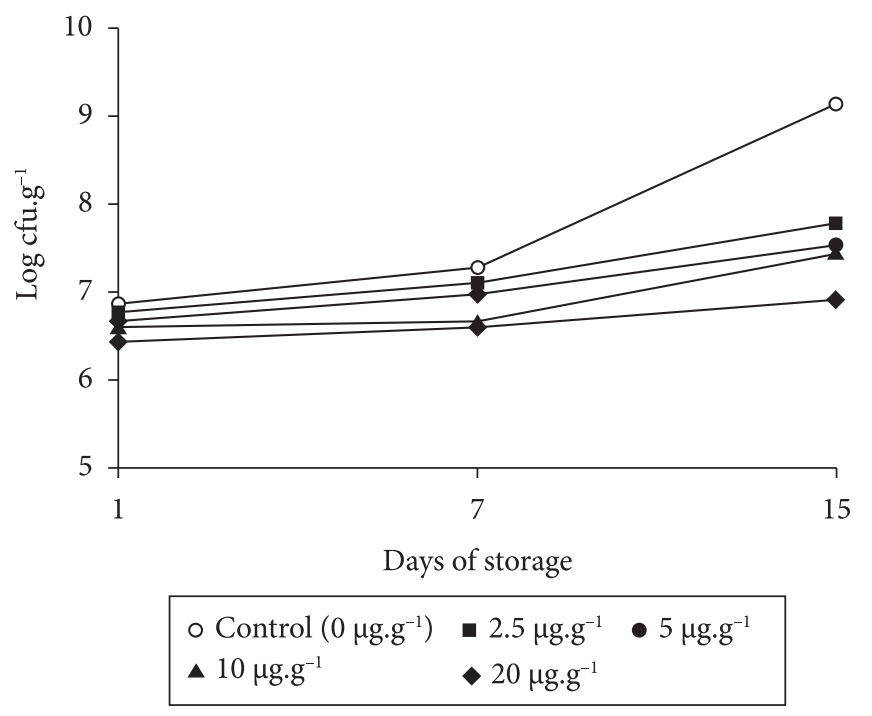

Figure 2. Effect of the essential oil from E. caryophyllata leaves on the count of mesophilic bacteria in vacuum packaged "coalho" cheese during refrigerated storage.

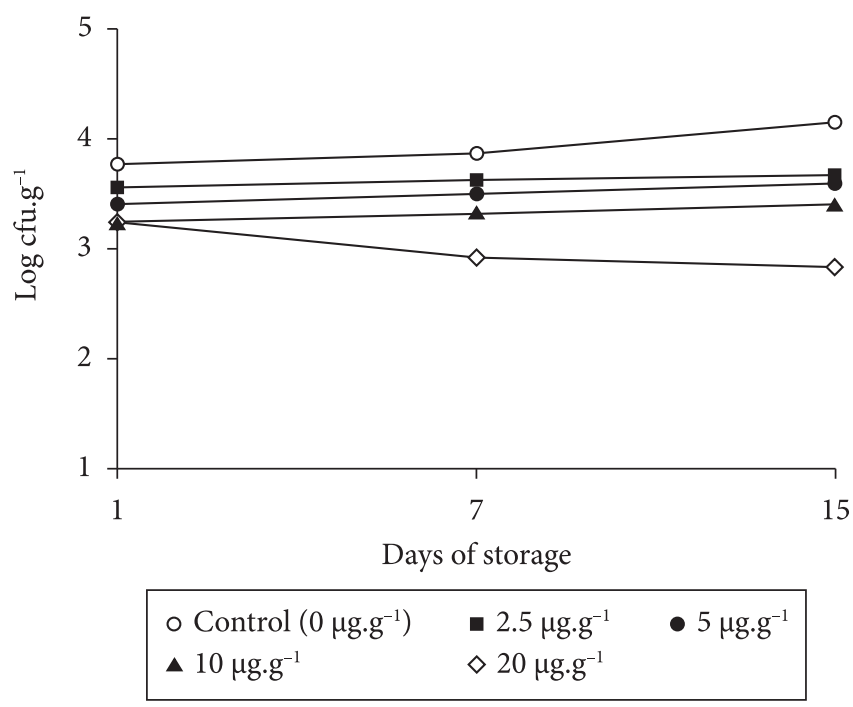

Figure 3. Effect of the essential oil from E. caryophyllata leaves on the count of fungi in vacuum packaged "coalho" cheese during refrigerated storage.

Gutierrez, Barry-Ryan and Bourke (2008) suggest that the lipid fraction of the food absorbs the components of essential oils thus decreasing the concentration in the aqueous phase and hence the antimicrobial effect. The protein content of foods may also be an influencing factor in the antimicrobial efficacy of oils. According to Juven et al. (1994), proteins in foods may be involved in complexation reactions with phenolic compounds in the oil. This complexation takes place via hydrogen bonds between phenolic groups and peptide links and via hydrophobic interactions. Still, the reduced water content in foods compared to that of the laboratorial media could impair the transfer of the antimicrobial to the active site in the microbial cell (SMITHPALMER; STEWART; FYFE, 2001).

\section{Conclusions}

Our data show the interesting antimicrobial property of the essential oil from E. caryophyllata leaves for a range of coalho cheese related microorganisms in laboratorial media and in a food matrix. This is relevant when the oil was able to present a pronounced inhibition of the autochthonous microflora of the cheese during refrigerated storage. These results encourage further research on the efficacy of other essential oils for controlling the microbial growth in this food, in addition to the evaluation of their impact on their sensory aspects.

\section{Acknowledgement}

The authors acknowledge the Conselho Nacional de Desenvolvimento Científico e Tecnológico (CNPq, Brazil) for the financial support.

\section{References}

ADAMS, R. P. Identification of essential oil components by gas chromatography/mass spectroscopy. Carol Stream: Allured, $1995.475 \mathrm{p}$.

ARORA, D.; KAUR, J. Antimicrobial activity of spices. International Journal of Antimicrobial Agents, v.12, n. 3, p. 257-262, 1999.

BRASIL. Ministério da Agricultura e do Abastecimento. Portaria ${ }^{\circ}$ 146, de 7 de março de 1996. Regulamento Técnico de Identidade e Qualidade do Queijo. Diário Oficial [da] República Federativa do Brasil, Poder Executivo, Brasília, DF, 15 ago. 1996.

BURT, S. A.; REINDERS, R. D. Antibacterial activity of selected plant essential oils against Escherichia coli O157:H7. Letters in Applied Microbiology, v. 36, n. 3, p. 162-167, 2003.

CAVALCANTE, J. F. M. et al. Processamento do queijo coalho regional empregando leite pasteurizado e cultura lática endógena. Ciências e Tecnologia de Alimentos, v. 27, n. 1, p. 205-214, 2007.

CHAIEB, K. et al. The chemical composition and biological activity of clove essential oil, Eugenia caryophyllata (Syzigium aromaticum L. myrtaceae): a short review. Phytotherapy Research, v. 21, n. 6, p. 501-506, 2007.

DEANS, S. Antimicrobial and antioxidant properties of Syzygium aromaticum L. Flavor Fragrance Journal, v. 10, n. 5, p. 323-328, 1995.

DEVLIEGHERE, F.; DEBEVERE, A. V. Chitosan: antimicrobial activity, interactions with food components and applicability as a coating on fruits and vegetables. Food Microbiology, v. 21, n. 2, p. 703-714, 2004.

ESPINEL-INGROFF, A. et al. Collaborative comparison of broth macrodilution and microdilution antifungal susceptibility tests. Journal of Clinical Microbiology, v. 30, n. 12, p. 3128-3145, 1992.

FEITOSA, T. et al. Pesquisa de Salmonella spp. e Listeria spp. e microrganismos indicadores de higiene de queijos de coalhos produzido no estado do Rio Grande do Norte. Ciência e Tecnologia de Alimentos, v. 23, n. 1, p. 162-165, 2003.

FICHI, G. et al. Efficacy of an essential oil of Cinnamomum zeylanicum against Psoroptes cuniculi. Phytomedicine, v. 14, n. 2, p. 227-231, 2007.

GILL, A. O. et al. Evaluation of antilisterial effect of cilantro oil on vacuum packed ham. International Journal of Food Microbiology, v. 73, n. 1, p. 83-92, 2002. 
GUSTAFSON, J. E. et al. Effects of tea tree oil on Escherichia coli. Letters in Applied Microbiology, v. 26, n. 3, p. 194-198, 1998.

GUTIERREZ, J.; BARRY-RYAN, C.; BOURKE, P. The antimicrobial efficacy of plant essential oil combinations and interactions with food ingredients. International Journal of Food Microbiology, v. 124, n. 1, p. 91-97, 2008.

JUVEN, B. J. et al. Factors that interact with the antibacterial action of thyme essential oil and its active constituents. Journal of Applied Bacteriology, v. 76, n. 6, p. 626-631, 1994.

LEITE JUNIOR, A. F. S. et al. Qualidade microbiológica de queijo de coalho comercializado a temperatura ambiente ou sobre refrigeração em Campina Grande - PB. Higiene Alimentar, v. 14, n. 76, p. $53-59,2000$.

LOPEZ DIAZ, T. M. L. et al. Effect of temperature, water activity, $\mathrm{pH}$ and some antimicrobials on the growth of Penicillium oslonii isolated from the surface of Spanish fermented meat sausage. Food Microbiology, v. 19, n. 1, p. 1-7, 2002.

McLAFFERTY, F. W.; STAUFER, D. The Wiley/NBS registry of mass spectral data. New York: John Wiley \& Sons, 1989. 453 p.

MENON, K. V.; GARG, S. R. Inhibitory effect of clove oil on Listeria monocytogenes in meat and cheese. Food Microbiology, v. 18, n. 6, p. 647-650, 1990.

MOREIRA, M. R. et al. Inhibitory parameters of essential oils to reduce a foodborne pathogen. LWT - Food Science and Technology, v. 38, n. 5, p. 565-570, 2005.

NUNEZ, L.; AQUINO, M. Antifungal properties of clove oil (Eugenia caryophylata) in sugar solution. Brazilian Journal of Microbiology, v. 32, n. 1, p. 123-126, 2001.

PERESI, J. T. M. et al. Queijo minas tipo frescal artesanal e industrial: qualidade microscopia, microbiológica e teste de sensibilidade aos agentes antimicrobiana. Higiene Alimentar, v. 15, p. 63-10, 2001.

RUBERTO, G. et al. Antioxidant and antimicrobial activity of Foeniculum vulgare and Crithmum maritimum essential oils. Planta Medica, v. 66, p. 687-693, 2000.

SAHIN, F. et al. Biological activities of the essential oils and methanol extract of Origanum vulgare ssp. vulgare in the Eastern Anatolia region of Turkey. Food Control, v. 15, p. 549-557, 2004.
SAMAPUNDO, S. et al. Can phenolic compounds be used for the protection of corn from fungal invasion and mycotoxin contamination during storage? Food Microbiology, v. 24, n. 5, p. 465-473, 2007.

SAMARASEKERA, R.; KALHARI, K. S.; WEERASINGHE, I. Mosquitocidal activity of leaf and bark essential oils of Ceylon Cinnamomum zeylanicum. Journal of Essential Oil Research, v. 17, n. 3, p. 301-303, 2005.

SENA, M. J.; CERQUEIRA, M. M. O. P.; MORAIS, C. F. A. Características físico-químicas de queijo de coalho comercializado em Recife - PE. Higiene alimentar, v. 14, n. 74, p. 41-44, 2000.

SIKKEMA, J.; BONT, J. A. M.; POOLMAN, B. Mechanisms of membrane toxicity of hydrocarbons. Microbiological Review, v. 59, n. 2, p. 201-222, 1995.

SMITH-PALMER, A.; STEWART, J.; FYFE, L. Antimicrobial properties of plant essential oils and essences against five important food-borne pathogens. Letters in Food Microbiology, v. 26, p. 118-122, 1998.

SMITH-PALMER, A.; STEWART, J.; FYFE, L. The potential application of plant essential oils as natural food preservatives in soft cheese. Food Microbiology, v. 18, n. 4, p. 463-476, 2001.

SOUZA, E. L et al. Effectiveness of Origanum vulgare L. essential to inhibit the growth of food spoiling yeasts. Food Control, v. 18, n. 5, p. 409-413, 2007.

van DEN DOOL, H.; KRATZ, D. J. A. A generalization of the retention index system including line temperature programmed gas liquid partition chromatography. Journal of Chromatography, v. 11, n. 1, p. 463-467, 1963.

VANDERZANT, C.; SPLITTSTOESSER, D. F. Compendium of methods for the microbiological examination of foods. 3th ed. Washington: American Public Health Association, 1992. 1919 p.

VILJOEN, A. et al. E. Osmitopsis astericoides (Asteraceae) - the antimicrobial activity and essential oil composition of a Cape-Dutch remedy. Journal of Ethnopharmacology, v. 88, n. 2, p. 137-143, 2003.

WILKINSON, J. M. et al. Bioactivity of Bachousia citriodira: antibacterial and antifungal activity. Journal of Agriculture and Food Chemistry, v. 51, n. 1, p. 76-81, 2003. 